\title{
PENINGKATAN KEMAMPUAN MENULIS EKSPOSISI MELAUI KEGIATAN MENULIS BERITA SISWA KELAS X MA PEMBANGUNAN UIN JAKARTA
}

\author{
Muttaqillah \\ Madrasah Pembangunan UIN \\ ahmad2qillah@gmail.com
}

\begin{abstract}
ABSTRAK
Penelitian yang bersifat tindakan kelas ini bertujuan untuk meningkatkan kemampuan menulis eksposisi pada siswa kelas X Madrasah Aliyah UIN Jakarta. Upaya untuk meningkatkan kemampuan menulis tersebut dilakukan melalui kegiatan menulis berita. Kegiatan menulis berita merupakan salah satu kegiatan untuk menggairahkan siswa dalam menulis karangan eksposisi. Penelitian ini dilakukan dengan dua siklus. Sebelum dilakukan tindakan, kemampuan menulis eksposisi siswa kelas $X$ belum memuaskan yaitu bawah KKM, sebesar 64, sedangkan KKM yang ditentukan sebesar 65. Lalu pada langkah berikutnya dilakukan tindakan dengan kegiatan menulis berita. Selama dilakukan tindakan, peneliti melakukan pengamatan untuk melihat motivasi, dan antusiasme siswa dalam kegiatan menulis berita. Lalu peneliti mewawancarai siswa untuk memberikan jawaban maupun tanggapan atas kegiatan menulis berita yang sudah dilakukan. Jawaban atas kegiatan menulis berita dengan menyatakan ya, dan tidak. Pada umumnya mereka menyatakan ya atas pertanyaan yang bersifat santai, senang, tergugah, dan puas. Demikian juga atas pertanyaan sangat senang, senang dan kurang seanag. Pada umumnya mereka menyatakan senang Sebelum dilakukan tindakan, nilai yang diperoleh siswa sebesar 48,85. Setelah peneliti melakukan tindakan siklus pertama, dapat diperoleh nilai kemampuan menulis seksposisi sebesar 66. Pada siklus kedua perolehan nilai sebesar 81. Peneliti juga melakukan pengolahan data kuantitatif dengan menggunakan statistik deskriptif. Secara kualitatif maupun kuantitatif, peningkatan kemampuan menulis eksposisi melalui kegiatan menulis berita di kelas X MA UIN Pembangunan Jakarta mengalami peningkatan.
\end{abstract}

Kata kunci: Peningkatan Kemampuan Menulis Eksposisi, Berita 
Muttaqilah : PeningkatanKemampuan Menulis Eksposisi Melalui Kegiatan Menulis Berita Siswa Kelas X MAPembangunan UIN Jakata

Website : https://jurnal.umj.ac.id/index.php/penaliterasiEmail : penaliterasi@umj.ac.id

\section{PENDAHULUAN}

Pengajaran Bahasa Indonesia di MA (Madrasah Aliyah) tidak berbeda dengan pengajaran Bahasa Indonesia di sekolahsekolah yang sederajat. Aspek-aspek yang dikuasai meliputi mendengarkan, membaca, berbicara, dan menulis. Yang membedakan antara MA dengan sekolah sederajat yang lainnya adalah dari segi alokasi waktu. Soal alokasi waktu tergantung dari lembaga masing-masing. Apakah akan memadatkan atau sesuai dengan instruksi standar kurikulum, bisa saja ditambah atau dikurangi.

Bahasa adalah suatu sistem lambang berupa bunyi, bersifat arbitrer digunakan oleh suatu masyarakat tutur untuk bekerja sama, berkomunikasi, dan mengidentifikasi diri. Abdul (Chaer, 2006: 1) Maka Bahasa Indonesia diajarkan di berbagai tingkatan satuan pendidikan di Indonesia. Karena Bahasa Indonesia adalah sebagai bahasa persatuan dan kesatuan, baik sekolah umum maupun kejuruan, seperti tertuang dalam Sumpah Pemuda 1928.

Hasil belajar Bahasa Indonesia di MA Pembangunan akan diketahui melalui survei, pengamatan dokumen, atau terjun langsung untuk memberikan evaluasi. Dapat pula melihat Penilaian Harian (PH) hasil Penilaian Akhir Semester (PAT), dan raport.

Dari pengamatan nilai di atas dapat diketahui tinggi dan rendahnya nilai Bahasa Indonesia setiap siswa. Peneliti akan melihat besaran aspek kemampuan yang berkaitan dengan menulis.

Dari hasil pengamatan peneliti, kemampuan menulis eksposisi siswa sangat rendah belum sesuai dengan KKM, yaitu sebesar yang ditentukan, yaitu dengan ratarata 64. Penyebabnya antara lain: a. Jarangnya siswa menulis eksposisi.

b. Alokasi waktu yang kurang.

c. Teknik yang digunakan kurang tepat.

d. Guru lebih memfokuskan pada pengajaran struktur daripada menulis eksposisi.

e. Pentingnya menulis eksposisi melalui kegiatan menulis berita tidak diutamakan.

Selain aitu, fakta menunjukkan bahwa kegiatan menulis berita dapat meningkatkan kemampuan menulis eksposisi. Sebagai bukti, di MA, MTs, dan MI Pembangunan UIN Jakarta ada kegiatan ekstrakurikuler jurnalistik. Dari kegiatan itu banyak siswa yang mampu menulis eksposisi dengan baik. Misalnya melaporkan hasil wawancara, membuat ringkasan buku atau sinopsis, serta ikut serta lomba mengarang ilmiah. Pada umumnya mereka dapat meraih kejuaraan dari tingkat kecamatan sampai tingkat nasional.

Di samping itu, Karena sulitnya untuk mengajarkan keterampilan menulis tertentu, semisal eksposisi, hal ini membutuhkan waktu, tempat, alat, dan metode tertentu yang dibutuhkan. Oleh karena tidak terlalu mudahnya mengajarkan keterampilan menulis, sepert yang dikatakan oleh J. B Heaton bahwa keterampilan menulis itu kompleks dan kadang-kadang sukar untuk mengajarkan, karena menuntut penguasaan yang tidak hanya retoris dan bersifat tatabahasa, tetapi juga konseptual dan mempertimbangkan unsur-unsur analitis. Analisis berikut mencoba untuk menggolongkan dan memvariasikan keterampilan untuk penulisan prosa yang baik. Ada lima komponen umum atau area utama dalam menulis.

1. Kemapuan berbahasa: mampu menulis dengan bahasa yang baik dan benar; 
Muttaqilah : PeningkatanKemampuan Menulis Eksposisi Melalui Kegiatan Menulis Berita Siswa Kelas X MAPembangunan UIN Jakata

Website : https://jurnal.umj.ac.id/index.php/penaliterasiEmail : penaliterasi@umj.ac.id

2. Keterampilan mekanis: kemampuan menggunakan huruf dan tanda baca sesuai. ejaan;

3. Ketepatan isi: kemampuan untuk berpikir kreatif, berkembang relevan;

4. Keterampilan gaya penulisan: kemampuan untuk menggunakan kalimat, paragraf, dan bahasa yang efektif,

5. Keterampilan mempertimbangkan: kemampuan untuk menulis sesuai tujuan, mampu untuk memilih, mengorganisir, dan menyampaikan informasi yang relevan (JB Heaton, 1989: 135) .

Kemampuan menulis menuntut seorang penulis agar mampu menggunakan polapola bahasa secara tertulis dalam mengungkapkan suatu gagasan atau pesan. Kemampuan menulis mencakup berbagai kemampuan, misalnya kemampuan memahami apa yang akan dikomunikasikan, penggunaan unsur-unsur bahasa, kemampuan mengorganisasi wacana dalam bentuk karangan, dan juga pemilihan gaya bahasa yang tepat.

Menurut hemat penulis, pada hakikatnya kemampuan menulis adalah mampu menuangkan pikiran, ide, maksud dan perasaan melalui perlambangan, atau huruf sesuai dengan tujuan yang ingin disampaikannya.

Pada penelitian ini memberikan penekanan peningkatan kemampuan menulis eksposisi dengan melalui kegiatan menulis berita pada tingkat Sekolah Lanjutan Atas yang sederajat, seperti Madrasah Aliyah.

Dari sinilah penulis meyakini bahwa kegiatan menulis berita dapat meningkatkan kemampuan menulis eksposisi.

Kemampuan menulis eksposisi dapat ditingkatkan melalui kegiatan menulis berita secara bertahap dan

berkesinambungan. Untuk meningkatkan kemampuan menulis eksposisi, harus ada pembiasaan tertentu kepada siswa. Kegiatan itu harus dilaksanakan dengan alokasi waktu yang cukup memadai. Atau secara khusus diberikan pelatihan menulis yang dapat memotivasi kegiatan menulis lainnya, salah satunya adalah dengan kegiatan menulis berita.

Faktor yang dimungkinkan dapat mendorong salah satu kemampuan menulis, adalah dengan memberikan kegiatan penulisan berita. Siswa akan diberikan pengetahuan khusus tentang menulis berita oleh ahli, termasuk guru yang mengajar sebagai motivator, dan fasilitator.

Dengan cara itulah dimungkinkan kemampuan menulis eksposisi akan lebih meningkat. Penulis beserta guru dan kolaboran, akan berupaya menerapkan pendekatan kegiatan menulis berita dengan melalui berbagai metode yang memungkinkan kegiatan itu dapat dilakukan. Metode ceramah, dan CBSA akan mendominasi upaya kegiatan menulis berita dalam rangka peningkatan menulis eksposisi.

Mengapa pelajaran Bahasa Indonesia yang cukup padat dibanding dengan pelajaran lain, tetapi kemampuan menulis dalam bidang pelajaran Bahasa Indonesia masih rendah. Apakah kurang motivasi, minat, bakat, dsb. Aspek psikologi, atau aspek lain yang menyebabkan rendahnya kemampuan menulis siswa.

Untuk meningkatkan kemampuan menulis perlu dilakukan penelitian tindakan, sehingga akan tampak solusi apa yang bisa dilakukan dalam melakukan langkah peningkatannya. Salah satu cara adalah mencari penyebabnya, kemudian penerapan metode yang tepat. 
Muttaqilah : PeningkatanKemampuan Menulis Eksposisi Melalui Kegiatan Menulis Berita Siswa Kelas X MAPembangunan UIN Jakata

Website : https://jurnal.umj.ac.id/index.php/penaliterasiEmail : penaliterasi@umj.ac.id

Khusus bidang peningkatan

kemampuan menulis eksposisi. Harus ada kegiatan tertentu, dengan teknik tertentu pula dalam rangka meningkatkan kemampuan menulis eksposisi. Gaya penulisan eksposisi sangat diperlukan sebagai suatu keterampilan menulis. Hal ini akan mengarah pada profesi siswa dalam menyalurkan bakat menulis. Dengan melalui kegiatan menulis berita, diharapkan kemampuan menulis eksposisi akan meningkat.

Untuk meneliti kemampuan menulis siswa, biasanya melalui kajian kuantitatif. Kajian kuantitatif pada dasarnya dilakukan untuk menguji teori atau hipotesis. Selanjutnya, penghitungan dalam kajian kuantitatif, dilakukan secara statistik. Oleh karena itu, data dalam kajian kuantitatif ini selalu berupa angka, dan biasa disebut angka kuantitatif. (Abdul Chaer 2007: 11)

Dalam prosedur penelitian kemampuan menulis siswa dalam bidang eksposisi, tentu menggunakan instrumen sebagai alat ukur. Instrumen ini akan dibuat sesuai dengan kategori kemampuan menulis eksposisi. Dari situlah guru atau peneliti dapat melakukan pengukuran untuk mendapatkan hasil kemampuan, apakah ada peningkatan atau tidak, setelah diberikan kegiatan menulis berita dalam beberapa siklus.

Kegiatan menulis berita atau jurnalistik, banyak diterapkan dalam pelatihan, kursus jurnalistik seperti warcil (wartawan cilik) di tingkat SD Jurnalistik SMP/SMA/mahasiswa. Hal itu dilakukan dalam rangka membina keterampilan menulis di majalah/koran/tabloid sekolah, mahasisiwa atau umum. Menurut hemat penulis pengajaran Bahasa Indonesia pun harus terarah menuju keterampilan tersebut.
Sebelum dimulai penelitian, siswa diberikan materi tentang kegiatan menulis berita. Baik dari segi pengertian, peranan, fungsi, langkah-langkah, serta ciri-cirinya. Mereka harus memahami itu semua. Kemudian diberikan tugas menulis berita. Sebagaimana pada umumnya, dalam proses pengajaran, siswa diberikan tes awal, tugas-tugas dan tes akhir. Tes itu dapat berupa angket maupun wawancara langsung (lisan). Hasil tes dan tugas dapat diukur melalui penilaian.

Penelitian ini juga melibatkan guru pengajar, dan ahli jurnalistik. Kemudian peneliti dan guru mempelajari secara mendalam tentang keiatan penulisan berita.

Penelitian ini dilakuka 3 kali pertemuan dan tiga kali melakukan tes, dalam melakukan penelitian kegiatan menulis berita. Secara umum penulis melakukan penelitian sampai siklus kedua. Subjek penelitian ini adalah siswa kelas X MA Pembangunan UIN Jakarta. Sebab kelas X menjadi subjek penelitian karena adanya suatau masalah yaitu rendahnya kemampuan menulis eksposisi. Sebenarnya masalah itulah merupakan sarat mutlak bagi setiap karya ilmiah.

Seperti juga yang dikemukan oleh Sabarti, masalah, merupakan salah satu komponen yang harus ada dalam karya ilmiah. Pada umumnya. Masalah penelitian timbul sebagai akibat adanya kesenjangan antara kondisi harapan atas kondisi yang seharusnya (das sollen) dan kondisi nyata (das sein). Kesenjangan ini meninmbulkan keraguan yang kerap kali berkembang menjadi pertanyaan. Pertanyaan tersebut merupakan masalah yang menuntut jawaban atau pemecahan (Sabarti Akhadiah, 2008: 19).

Data penelitian ini terdiri atas kualitatif dan kuantitatif. Data kualitatif itu antara 
Muttaqilah : PeningkatanKemampuan Menulis Eksposisi Melalui Kegiatan Menulis Berita Siswa Kelas X MAPembangunan UIN Jakata

Website : https://jurnal.umj.ac.id/index.php/penaliterasiEmail : penaliterasi@umj.ac.id

lain: keantusiasan, keseriusan,

kedisiplinan, ketertiban, kemandirian, kerapihan, kenyamanan, ketenangan, kekompakan, dan lain-lain.

Sedangkan Data ini berupa data-data empiris tentang kemampuan siswa dalam menulis eksposisi, yang dilakukan melalui tes awal sebelum diberikan tindakan teori dan konsep kegiatan menulis berita. Tes akhir dilakukan setelah siswa diberikan pengetahuan tentang menulis berita dan tindakan kegiatan menulis berita. Data tes awal dan akhir, selanjutnya akan dikomparasikan untuk mengetahui tingkat fluktuasi kemampuan siswa dalam menulis eksposisi.

Berita adalah suatu informasi yang disampaikan oleh media kepada khlayak, informasi yang disampaikan itu selalu baru dan menarik. Teknik penulisan itulah yang penulis lakukan dalam penelitian ini.

Pemilihan penelitian ini dilatarbelakangi oleh maraknya siswa di Madrasah Pembangunan yang mengikuti kegiatan pelatihan jurnalistik. Dengan kegiatan itu itu, siswa termotivasi untuk menulis. Hasilnya tercermin dalam tulisan-tulisan mereka yang ditampilkan di majalah sekolah "Al-Asri."

\section{METODE PENELITIAN}

Penelitian ini adalah menggunakan metode penelitian tindakan kelas. Penelitian Tindakan Kelas (PTK) merupakan suatu bentuk penelitian yang bersifat reflektif dengan melakukan tindakan-tindakan tertentu agar dapat memperbaiki dan atau meningkatkan praktik pembelajaran di kelas secara lebih profesional. Berdasarkan pada pengertian di atas, maka kegiatan PTK harus senantiasa terkait dengan persoalan praktik pembelajaran sehari-hari yang dihadapi oleh guru (Basuki Wibawa, 2003: 3)

Penelitian tindakan adalah suatu proses yang dirancang untuk meberdayakan semua partisipan dala proses (siswa, guru, dan peserta lainnya) dengan maksud untuk meningkatkan praktik yang diselenggarakan dalam pengalaman pendidikan. Semua partisipan merupakan anggota aktif dalam proses penelitian (Emzir, 2008:233).

Penelitian Tindakan kelas menulis eksposisi yang dilakukan melalui kegiatan menulis berita, mendapatkan sambutan baik dari siswa kelas X. Hal ini tercermin dari hasil pengamatan di lapangan yang dilakukan oleh peneliti, dan kolaborator. Penulis sendiri mengamati apa yang peneliti lakukan mereka sangat antusias mengikutinya.

Eksposisi adalah sauatu tulisan yang bersifat memberikan penjelasan kepada orang lain, seperti peristiwa, ilmu pengetahui, social, politik, budaya, dan sebagainya.

Menurut Sudarno dan Eman A. Rahman Eksposisi adalah bentuk karangan yang menyampaikan informasi, menjelaskan atau menerangkan sesuatu kepada pembaca. Faktor dalam eksposisi berguna untuk menambah jelasnya sesuatu yang dipaparkan. Yang tergolong eksposisi di antaranya: buku-buku pelajaran, surat, laporan, artikel, makalah, skripsi. Dalam kegiatan lisan, eksposisi tampak pada guru yang sedang mengajar, khatib pada waktu berkhutbah, penceramah, juru dakwah, dll. Pada eksposisi pun tampak suatu maksud pemberian tambahan pengetahuan atau pengertian. (Sudarno dan Eman A. Rahman, 2000: 118).

Sedangkan berita adalah keterangan mengenai kejadian atau peristiwa yang hangat. Penulisan berita merupakan suatu 
Muttaqilah : PeningkatanKemampuan Menulis Eksposisi Melalui Kegiatan Menulis Berita Siswa Kelas X MAPembangunan UIN Jakata

Website : https://jurnal.umj.ac.id/index.php/penaliterasiEmail : penaliterasi@umj.ac.id

cara untuk mengekspos suatu peristiwa yang baru dan menarik bagi khalayak.

Kata berita berasal dari Bahasa Sansekerta, yakni vrit, yang kemudian masuk ke dalam Bahasa Inggris menjadi write. Arti sebenarmya ialah 'ada' atau 'terjadi.' Sebagian ada yang menyebutnya vritta, masuk ke dalam Bahasa Indonesia menjadi 'berita' atau 'warta (Ahmad Y. Samanto, 2002: 112).

Analisis data kualitatif ini menggunakan acuan teori Miles dan Huberman yang menjelaskan bahwa analisis kualitatif meliputi: (1) reduksi data, (2) penyajian data secara matrik, bagan, matrik daftar cek, dan (3) penarikan kesimpulan (Mattew B. Milles \& A. Michel Huberman, 1986: 79).

Berita adalah sesuatu yang termasa atau baru yang dipilih oleh wartawan untuk dimuat dalam surat kabar, karena ia dapat menarik atau mempunyai makna bagi pembaca surat kabar, atau karena ia dapat menarik pembaca (Bambang Trimansyah, 1998: 42).

Berita juga dikatakan sebagai laporan tercepat mengenai fakta atau ide terbaru yang benar, menarik dan atau penting bagi sebagian besar khalayak melaui media berkala seperti surat kabar, radio, televisi, atau internet (A. S. H. Sumadiria, 2006: 65).

Kalimat-kalimat dalam menulis berita. Dalam pebulisan berita yang dipaparkan adalah hal-hal pokok. Bagian terpenting didahulukan daripada yang kurang penting. Oleh karena itu ada beberapa patokan yang harus diperhatikan dalam penulisan berita.

Beberapa patokan dalam menulis berita: (a) Gunakan kalimat-kalimat pendek; (b) Gunakan bahasa biasa yang mudah dipahami orang; (c) Gunakan bahasa sederhana dan jernih pengutaraannya; (d) Gunakan bahasa tanpa kalimat majemuk; (e) Gunakan bahasa dengan kalimat aktif dan bukan kalimat pasif; (f) Gunakan bahasa padat dan kuat; (g) Gunakan bahasa positif dan bukan bahasa negatif (Rosihan Anwar, 1994: 12).

\section{Kegiatan Menulis Berita}

Penulisan berita adalah bagian dari karangan eksposisi. Namun kegiatan penulisan berita ini sangat di sukai oleh para siswa di lingkungan Madrasah Pembangunan UIN Syarif Hidayatullah Jakarta.

Di lingkungan sekolah tersebut ada program ekstrakulikuler yang cukup diminati para siswa adalah pelatihan jurnalistik. Pelatihan ini di sesuaikan dengan tingkatan masing-masing dari mulai MI, MTs, sampai dengan MA. Dapat dikatakan bahwa antusiasme siswa dalam mengikuti kegiatan jurnalistik sangat marak.

Langkah-langkah penulisan berita ini dilakukan dengan cara membaca berita di koran, televisi, dan internet. Kemudian mereka mencari unsur-unsur berits ysng terpenting. Berita yang dibaca harus menarik sesuai dengan minatnya. Langkah selanjutnya adalah menirukan menulis berita dengan cara mengganti peristiwanya, tempat kejadian, dan sebagainya sesuai dengan karakter berita yang mengandung unsur $5 \mathrm{~W}$ dan $1 \mathrm{H}$.

Kegiatan ini diulang sesuai dengan siklus yang ditentukan yaitu dua siklus. Ada pretes sebelum mereka melakukan kegiatan pada siklus pertama untuk mengambil hasil kemampuan menulis eksposisi. Baru kemudian siklus kesatu dan kedua. Dari tahapan-tahapan itu hasil yang didapatkan berbeda-beda.

Perlakuan itu dilaksanakan berdasarkan teori indakan kelas yang dilakukan oleh Kurt Levin yaitu (1) perencanaan 
Muttaqilah : PeningkatanKemampuan Menulis Eksposisi Melalui Kegiatan Menulis Berita Siswa Kelas X MAPembangunan UIN Jakata

Website : https://jurnal.umj.ac.id/index.php/penaliterasiEmail : penaliterasi@umj.ac.id

(planning), (2) tindakan (acting), (3) pengamatan (observing), dan (4) refleksi (reflecting) (Syamsudin dan Vismaia 2006: 195).

Penelitian tindakan ini dilakukan di Madrasah Aliyah (MA) Pembangunan UIN Jakarta kelas X. Sekolah tersebut terletak di Jalan Ibnu Taimia IV Kompleks UIN Syarif Hidayatullah, Jakarta. Selanjutnya, penelitian tindakan ini direncanakan akan berlangsung selama tiga bulan, antara bulan Januari - Mare, tepat pada semester genap.

\section{Pelaksanaan Penelitian}

Berikut adalah tabel pelaksanaan penelitian tindakan kelas yang sesuai dengan karakteristik penelitian tindakan kelas di bidang pendidikan dan pengajaran.

\begin{tabular}{|l|l|}
\hline Siklus I & $\begin{array}{l}\text { 1. } \\
\text { Kegiatan menulis berita dan } \\
\text { pengamatan }\end{array}$ \\
& $\begin{array}{l}\text { 2. } \\
\text { Tes menulis eksposisi dan } \\
\text { pengamatan }\end{array}$ \\
& $\begin{array}{l}\text { 3. } \\
\text { 4. }\end{array}$ \\
\hline Siklus II & $\begin{array}{l}\text { 1. } \\
\text { Kefleksiatan menulis berita dan } \\
\text { pengamatan }\end{array}$ \\
& $\begin{array}{l}\text { 2. } \\
\text { Tes menulis eksposisi dan } \\
\text { 3. Anamatan }\end{array}$ \\
& 4. Refleksi data \\
\hline
\end{tabular}

Pelaksanaan penelitian tersebut dilakukan bersama para kolaborator. Kolaborator yang peneliti minta adalah guru-guru MA MP UIN Jakarta.

Prasiklus yang dilakukan untuk mendapatkan hasil sebagai dasar untuk memperoleh hasil agar mengetahui kemampuan siswa dalam menulis karangan eksposisi. Pelaksaan prasiklus ini.
Pengajaran kegiatan penulisan berita tidak diberikan kepada siswa. Artinya pengetahuan penulisan berita yang mereka peroleh masih minim.

\section{Instrumen Penelitian Kualitatif}

Intrumen kualitatif yang digunakan dalam penelitian tersebut adalah intrumen pengamatan yang dilakukan oleh kolaborator antara lain: ketertiban, keantusiasan, dan kemandirian. Ketiga indikator intrumen tersebut dipantau oleh kolaborator selama observasi penelitian.

Berkkaitan dengan PTK, peneliti menyiapkan angket pengamatan yang digunakan oleh kolaborator untuk mengontrol jalannya proses pembelajaran kegiatan menulis berita antara lain:

1. Ketertiban siswa yang terdiri atas: (a) menunjukkan perilaku sangat tertib pada saat mengikuti pelajaran; (b) sikap tertib pada saat mengikuti pembelajaran; (c) sikap kurang tertib pada saat mengikuti pembelajaran.

2. Keantusiasan siswa, meliputi: (a) sangat antusias dalam mengikuti pembelajaran; (b) menunjukkan perilaku yang antusias mengikuti pembelajaran; (c) kurang antusias dalam mengikuti pelajaran.

3. Kemandirian, di antaranya: (a) sangat mandiri dalam mengikuti proses pembelajaran; (b) mandiri dalam mengikuti proses pembelajaran; (c) kurang mandiri dalam mengikuti proses pembelajaran.

Selanjutnya peneliti juga melakukan wawancara tertulis dengan instrumen sbb:

1. Apakah siswa merasa rileks (santai) pada saat mengikuti proses pembelajaran kegiatan menulis berita. 
Muttaqilah : PeningkatanKemampuan Menulis Eksposisi Melalui Kegiatan Menulis Berita Siswa Kelas X MAPembangunan UIN Jakata

Website : https://jurnal.umj.ac.id/index.php/penaliterasiEmail : penaliterasi@umj.ac.id

2. Apakah siswa merasa senang pada saat mengikuti proses pembelajaran kegiatan menulis berita.

3. Apakah ada kesulitan yang dialami siswa pada saat proses pembelajaran kegiatan menulis berita.

4. Apakah siswa merasa mendapat pengalaman baru pada saat mengikuti proses pembelajaran berita.

5. Apakah siwa merasa tergugah semangatnya untuk terus mengikuti proses pembelajaran.

6. Apakah siswa merasa bahwa kegiatan menulis berita dapat memudahkan dalam rangka menulis eksposisi.

7. Apakah siswa merasa puas dalam kegiatan menulis berita.

\section{Instrumen Penelitian Kuntitatif}

Adapun instrumen untuk pengambilan data kuantitatif secara garis besar terdiri atas: Isi, bahasa , dan wacana

1. Isi mencakup: (a) kesesuaian antara judul dengan isi; (b) kesesuaian antara, tema, tujuan, kerngka karangan, dan paragraf.

2. Bahasa meliputi: (a) struktur kalimat yang memiliki kohesi dan koherensi (b) diksi atau pilihan kata yang tepat.

3. Wacana yang meliputi: (a) ejaan atau ketepatan menulis huruf dan tanda baca (b) Kerapian: bersih tanpa coretan, dan lurus sesuai dengan garis tepi.

\section{Metode yang Digunakan}

Kelas X MA Pembangunan terdiri atas 3 kelas yaitu Xa, Xb, dan Xc. Sebagai sampel dan pupulasi adalah kelas Xc yang berjumlah 27 siswa.

Pada siklus ini perencanaan yang peneliti siapkan adalah media berita berupa koran yang berada di perpustakaan. Kedua, media audio visual, dan ketiga menjelaskan tentang teori-teori penulisan berita. Jadi ada ada beberapa metode yang peniliti sajikan pertama ceramah, kedua audio visual, dan ketiga membaca dan menulis berita melalui media cetak.

Dalam metode ceramah peneliti menjelaskan beberapa hal berkaitan dengan penulisan berita, di antaranya menjelaskan pengertian, jenis-jenis, langkah-langkah menulis berita, dan cara menulis berita dengan kalimat-kalimat jurnalistik yang tepat, dan seterusnya.

Kemudian pada metode audio visual, beberapa contoh berita peniliti tayangkan, teutama berita-berita yang menarik bagi siswa, dari mulai fasion, makanan, olah raga sampai dengan filtrip.

Membaca dan menulis, mereka mencari bahan bacaan berita yang cocok dengan keinginan mereka. Sebagian besar siswa putra membaca berita olahraga, dan sebagian besar wanita membaca berita bekaitan dengan makanan dan mode pakaian.

Usai kegiatan di atas, peneliti melakukan tes penulisan berita dan karangan eksposisi yang lain yang mereka sukai. Namun demikian pada siklus pertama dan kedua memiliki perbedaan hasil, baik secara kuantitaif maupun kualitatif.

Usai siklus pertama berlangsung, peneliti mengadakan refleksi, yaitu dengan melakukan brifing bersama dengan kolaborator untuk mencari masukan mengenai beberapa hal yang belum cukup. Berdasarkan hasil refleksibersama peneliti menemukan, metode yang digunakan belum maksimal. Dari hasil refleksi itulah padada siklus berikutnya peneliti melakukan penelitian sesuai dengan saran dan masukan dari para kolaborator, sehingga mendapatkan hasil yang memuaskan. 
Muttaqilah : PeningkatanKemampuan Menulis Eksposisi Melalui Kegiatan Menulis Berita Siswa Kelas X MAPembangunan UIN Jakata

Website : https://jurnal.umj.ac.id/index.php/penaliterasiEmail : penaliterasi@umj.ac.id

\section{HASIL DAN PEMBAHASAN}

Berikut ini adalah hasil penelitian yang dilakukan selama kurun waktu seperti yang tersebut di awal. Penelitian tindakan kelas di kelas X MA Pembangunan UIN jakarta dari siklus satu ke siklus dua memiliki hasil yang berbeda. Jumlah subjek sebanyak 27 siswa.

\section{Data Kualitatif Siklus ke-1}

Data kualitatif siklus pertama hasil pengamatan sebagai bersama kolaborator selama dalam proses pembelajaran berikut.

\begin{tabular}{|l|l|l|l|l|}
\hline $\begin{array}{l}\text { Indi- } \\
\text { kator }\end{array}$ & Sangat & sedang & Kurang & $\begin{array}{l}\text { Jum- } \\
\text { lah }\end{array}$ \\
\hline Tertib & 10 & 10 & 7 & 27 \\
\hline $\begin{array}{l}\text { Antu- } \\
\text { sias }\end{array}$ & 8 & 8 & 11 & 27 \\
\hline $\begin{array}{l}\text { Man- } \\
\text { diri }\end{array}$ & 10 & 7 & 10 & 27 \\
\hline Jumlah & 26 & 25 & 28 & 81 \\
\hline Persen & $33 \%$ & $32 \%$ & $35 \%$ & $\begin{array}{l}100 \\
\%\end{array}$ \\
\hline
\end{tabular}

Capaian yang diperoleh dari pemantauan sikap oleh kolaborator dalam peroses pembelajaran, jawaban yang positif yaitu sangat dan sedang berkisar $33 \%+32 \%$ $=65 \%$.

Kemudian data hasil wawancara tertulis kepada para siswa kelas X MA Pembangunan UIN Jakarta, dengan mencontreng pernyataan tertulis ya dan tidak.

\begin{tabular}{|l|l|l|l|}
\hline Indikator & Ya & Tidak & Jumlah \\
\hline Santai & 18 & 9 & 27 \\
\hline Senang & 16 & 11 & 27 \\
\hline Mudah & 16 & 11 & 27 \\
\hline
\end{tabular}

\begin{tabular}{|l|l|l|l|}
\hline $\begin{array}{l}\text { Mendapat } \\
\text { pengalaman } \\
\text { baru }\end{array}$ & 17 & 10 & 27 \\
\hline Tergugah & 11 & 16 & 27 \\
\hline $\begin{array}{l}\text { Sangat } \\
\text { mudah }\end{array}$ & 19 & 8 & 27 \\
\hline Puas & 17 & 10 & 27 \\
\hline Jumlah & 114 & 75 & 189 \\
\hline Persen & $\mathbf{6 0 \%}$ & $40 \%$ & $100 \%$ \\
\hline
\end{tabular}

Dari tabel di atas, bagian yang termasuk indikator positif yang menjawab ya, seperti santai, senang, mendapat pengalaman baru, tergugah, lebih mudah dan puas adalah $60 \%$. Dan indikator negatif, yang menjawab tidak sebesar $40 \%$.

Secara ringkas data kualitatif siklus pertama dari hasil pengamatan oleh kolaborator dan hasil wawancara tertulis oleh peneliti sebagai berikut: (a) hasil pengamatan yang mencakup tertib, antusias, dan mandiri sebesar $65 \%$, dan (b) hasil wawancara yang mencakup santai, senang, mendapat pengalaman baru, tergugah, lebih mudah dan puas adalah $60 \%$.

Kemudian peneliti melakukan refleksi bersama kalobarator dengan menerima beberapa masukan dan pertimbangan untuk mengatasi berbgai kekurangan yang dilakukan, maka atas saran-saran dari kawan-kawan peneliti memutuskan untuk melakukan penelitian tindakan pada siklus kedua.

\section{Data Kualitatif Siklus ke-2}

Pada siklus kedua ini peneliti melkukan penelitian ulang dengan semua metode yang direncanakan seperti metode, ceramah, audiovisual, diskusi, dan observasi. Pada siklus kedua ini subjek 
Muttaqilah : PeningkatanKemampuan Menulis Eksposisi Melalui Kegiatan Menulis Berita Siswa Kelas X MAPembangunan UIN Jakata

Website : https://jurnal.umj.ac.id/index.php/penaliterasiEmail : penaliterasi@umj.ac.id

penelitian langsung melakukan peliputan berita di lapangan. Salah satu kegiatannya adalah mereka terjun langsung mengamati pertandingan futsal antar kelas.

Data kualitatif yang peneliti peroleh dari hasil pengamatan bersama kolabolator adalah sebagai berikut. Mereka membuat catatan-catatan kecil sebagai bahan penulisan eksposisi melauai kegiatan menulis berita. Hasil pengamatan sikap dari kegiatan tersebut adalah:

\begin{tabular}{|l|l|l|l|l|}
\hline $\begin{array}{l}\text { Indi- } \\
\text { kator }\end{array}$ & Sangat & $\begin{array}{l}\text { Sedan } \\
\mathrm{g}\end{array}$ & Kurang & $\begin{array}{l}\text { Jum- } \\
\text { lah }\end{array}$ \\
\hline Tertib & 15 & 10 & 2 & 27 \\
\hline $\begin{array}{l}\text { Antu- } \\
\text { sias }\end{array}$ & 15 & 10 & 2 & 27 \\
\hline $\begin{array}{l}\text { Man- } \\
\text { diri }\end{array}$ & 10 & 7 & 10 & 27 \\
\hline Jumlah & 30 & 27 & 24 & 81 \\
\hline Persen & $\mathbf{3 7 \%}$ & $\mathbf{3 3 \%}$ & $30 \%$ & $\begin{array}{l}100 \\
\%\end{array}$ \\
\hline
\end{tabular}

Hasil pengamatan sikap siswa dari para kolaborator dan peneliti dspst dikstsksn baik atau positif dengan perolehan mencapai $70 \%$ yaitu dari hasil $37 \%+33 \%=70 \%$. Meningkat di atas $2,5 \%$ yaitu $5 \%$.

Sedangkan data kualitatif hasil wawancara kepada siswa sebagai berikut.

\begin{tabular}{|l|l|l|l|}
\hline Indikator & Ya & Tidak & Jumlah \\
\hline Santai & 23 & 4 & 27 \\
\hline Senang & 22 & 5 & 27 \\
\hline Mudah & 11 & 16 & 27 \\
\hline $\begin{array}{l}\text { Mendapat } \\
\text { pengalaman } \\
\text { baru }\end{array}$ & 23 & 4 & 27 \\
\hline
\end{tabular}

\begin{tabular}{|l|l|l|l|}
\hline Tergugah & 13 & 14 & 27 \\
\hline $\begin{array}{l}\text { Sangat } \\
\text { mudah }\end{array}$ & 23 & 4 & 27 \\
\hline Puas & 24 & 3 & 27 \\
\hline Jumlah & 139 & 50 & 189 \\
\hline Persen & $\mathbf{7 4 \%}$ & $26 \%$ & $100 \%$ \\
\hline
\end{tabular}

Hasil wawancarar dengan pernyataan santai, senang, mudah, mendapat pengalaman baru, terggah, sangat mudah, dan puas mencapai $74 \%$. Hasilnya meningkat sebesar 34\%.

Dapat dilihat dalam diagram berikut:

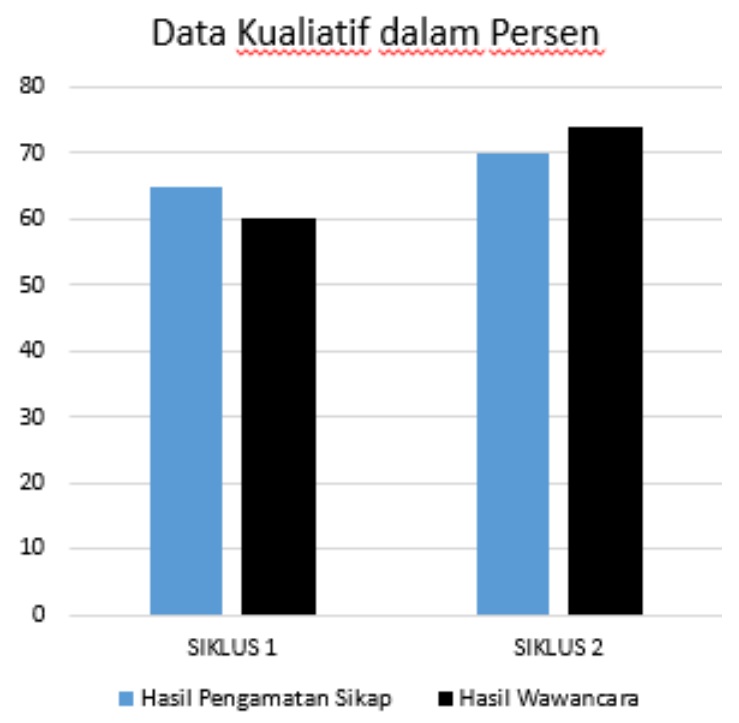

Dari diagram di atas diketahui, sikap baik atau positif siswa dalam pengamatan ketika proses pembelajaran menulis eksposisi melalui kegiatan menulis berita sebanyak 65\%. Demikian juga dengan hasil wawancara dalamproses pembelajaran tersebut sejumlah $60 \%$.

Pada siklus ke-2. Hasil pengamatan sikap yang positif sebesar $70 \%$, dan wawancara sebesar $74 \%$. Jadi ada peningkatan pada siklus kedua rata-rata secara untuk sikap positif siswa meningkat $5 \%$ dan hasil wawancara meningkat $14 \%$. 
Muttaqilah : PeningkatanKemampuan Menulis Eksposisi Melalui Kegiatan Menulis Berita Siswa Kelas X MAPembangunan UIN Jakata

Website : https://jurnal.umj.ac.id/index.php/penaliterasiEmail : penaliterasi@umj.ac.id

\section{Data Kuantitatif}

Data ini pun dapat dilihat dari nlai ratarata siswa yang mengikuti pembelajaran kegiatan menulis berita. Nilai KKM bahasa Indonesia adalah 65 . Sedangkan perolehan nilai pada siklus ke-1 diperoleh nilai ratarata sebesar 66 dan siklus ke-2 sebesar 81. Aspek-aspek yang dinilai adalah Isi, bacaan, dan wacana. Keduanya dapat dilihat diagram di bawah ini.

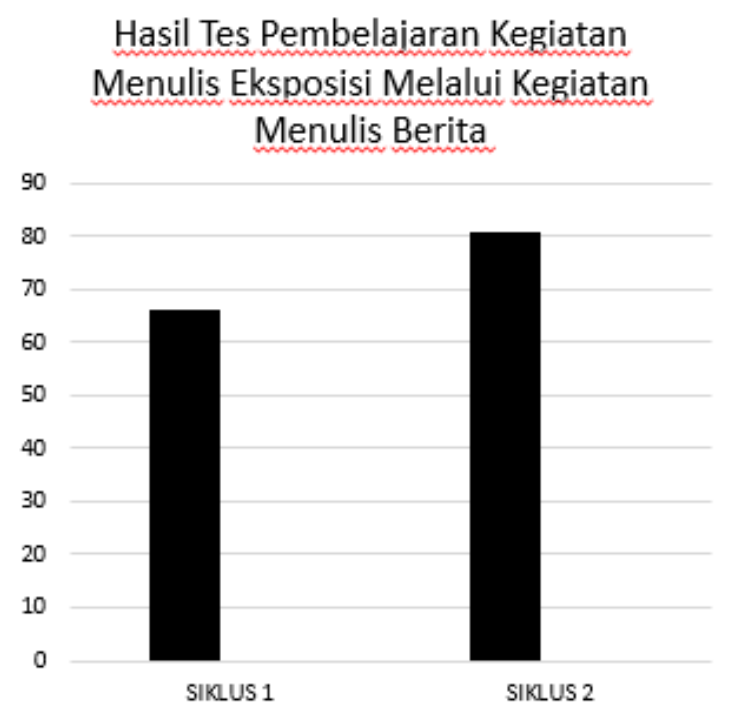

Tampak perbedaan dari kedua siklus di atas baik secara kualitatif maupun kuantitatif seperti yang dipaparkan di atas.

Data kantitatiff itu apabila dihitung dengan rumus statistik uji-t sebagai berikut.

\begin{tabular}{|c|c|c|c|c|}
\hline Responden & $\begin{array}{c}\text { Siklus } \\
\text { I }\end{array}$ & $\begin{array}{l}\text { Siklus } \\
\text { II }\end{array}$ & $\begin{array}{l}\text { Deviasi } \\
(\mathrm{d})\end{array}$ & $\mathrm{d}^{2}$ \\
\hline 27 & $\mathbf{1 3 1 9}$ & $\mathbf{2 1 8 9}$ & 404 & 9776 \\
\hline
\end{tabular}

$$
\begin{aligned}
& \sum_{n=27} d=404 \\
& d=\frac{\sum d}{n}
\end{aligned}
$$

$$
d=\frac{404}{27} d=\frac{404}{27}=14,96
$$$$
\sum d^{2} \sum d^{2}=9776
$$$$
t=\frac{d}{\sqrt{\frac{\sum d^{2}-\left(\sum d\right)^{2} / n}{n(n-1)}}}
$$$$
t=\frac{d}{\sqrt{\frac{\sum d^{2}-\left(\sum d\right)^{2} / n}{n(n-1)}}}=
$$$$
\frac{14,96}{\sqrt{\frac{9776-(404)^{2} / 27}{27(27-1)} \sqrt{\frac{9776-(404)^{2} / 27}{27(27-1)}}}}=
$$$$
\frac{14,96}{\sqrt{\frac{9776-6.045}{702}} \sqrt{\frac{9776-6.045}{702}}}
$$$$
\mathrm{t}=\sqrt{\frac{14,96}{\frac{3.730}{702}} \sqrt{\frac{3.730}{702}}}=\frac{14,9614,96}{\sqrt{5,314} \sqrt{5,314}}=
$$

$14,9614,96$

$2,302,30=6,50$

$\mathrm{t}=6,50 * *>\operatorname{tabel}(0,05)=1,8$. Jadi sangat signifikan.

\section{KESIMPULAN}

Dapat peneliti simpulkan dari hasil penelitian tindakan kelas yang peneliti lakukan di Madrasah Aliyah Kelas X pada semester genap, dapat dinyatakan bahwa kemampuan menulis eksposisi melalui kegiatan menulis berita memilki peningkatan yang cukup signifikan.

Baik dari sisi kualitatif maupun kuantitatif. Dapat peneliti paparkan: perolehan nilai secara kulitatif pada siklus pertama sebesar $65 \%$ pada bagian pengamatan pada pengukuran ketertiban keantusiasan dan kemandirian. Kemudian diperoleh angka $60 \%$ pada hasil 
Muttaqilah : PeningkatanKemampuan Menulis Eksposisi Melalui Kegiatan Menulis Berita Siswa Kelas X MAPembangunan UIN Jakata

Website : https://jurnal.umj.ac.id/index.php/penaliterasiEmail : penaliterasi@umj.ac.id

wawancara. Jadi rata-rata perolehan pada siklus ke-1 sebesar 62,5\%.

Pada siklus ke-2 perilaku positif siswa dalam pembelajaran menulis eksposisi melalui kegiatan menulis berita adalah sikap-sikap positif sebesar $70 \%$ dan tanggapan siswa terhadap pembelajaran tersebut bernilai positif sebesar $74 \%$ sehingga rata-rata perolehan $72 \%$.

Jadi perbedaan atau selisih antara siklus pertama dan kedua sebesar 9,5\%.

Untuk perolehan nilai kuantitatif pada siklus pertama sebesar 66 dan pada siklus kedua sebesar 71, jadi selisih siklus kei dan ke-2 pada penelitian kuantitatif sebesar 6 poin. Jadi apabila secara kualitatif mengalami peningkatan kemampuan menulis eksposisi melalui kegiatan menulis berita, begitu juga pada aspek kualitatifnya.

\section{REFERENSI}

Akhadiah, Sabarti. 2008. Penulisan Ilmiah. Jakarta, PPs Uhamka.

Anwar, Rosihan. 1993. Bahasa Jurnalistik dan Komposisi, Pradnya Paramita Jakarta.

Basuki Wibawa. 2003, Penelitian Tindakan Kelas-Bahan Ajar Guru Bantu, Jakarta: Gramedia.

Chaer, A. 2007, Kajian Bahasa. Struktur Internal, Pemakaian dan Pembelajaran. Jakarta: PT Rineka Cipta.

-----------. 2006 Tata Bahasa Praktis Bahasa Indonesia. Jakarta: Rineka Cipta.

Milles, Mattew B. \& A. Michel Huberman. 1986. Qualitative Data Analysis: Sourcebook of New Methods, London: Sage Publication.
Emzir, 2008. Metodologi Penelitian Kualitatif. Jakarata: Rajawali Press.

Heaton, J. B. 1989 Writing English Language.London and New York: Longman.

Samantho, Ahmad Y. 2002. Jurnalistik Islam. Jakarta: Harakah.

Sudarno; Rahman, E. A. 2000. Terampil Berbahasa Indonesia. Jakarta: PT Hikmat Syahid Indah.

Sumadiria, S. S. H., 2006. Jurnaistik Indonesia Menulis Berita dan Feature. Bandung: Simbiosa Rekatama Media. 